\title{
Pengelolaan Sektor-Sektor Publik Ekonomi dalam Kompilasi Hukum Ekonomi Syariah
}

\author{
Azizah Azis \\ Institut Agama Islam Muhammadiyah Sinjai, Indonesia \\ e-mail: azizah.azis2014@gmail.com
}

\begin{abstract}
ABSTRAK
This paper is intended to add scientific insight into the management of the Islamic economic sector, especially in managing the public sectors of the economy. The problem raised in this paper is the position of the public sectors of the economy in meeting the basic needs of the community and managing public assets or state assets as part of the public sector of the economy in increasing state revenues according to the Compilation of Sharia Economic Law. The economic sector-public sector should be understood more than just an idea, given the vastness and breadth of this section managed by individuals or partners who ignore the interests and benefits of the people. As it is understood together, the public economic sectors basically provide and guarantee the availability of an infrastructure to improve the fulfillment of the economic needs of the community, in addition to being a sector that produces goods and services for defense education, and security as well as everything related to the public sector economy. Thus, this paper can present implications in accordance with the aims and objectives.

Kata Kunci: KHES, Pengelolaan, Sektor-sektor publik, harta public, harta negara.
\end{abstract}

\section{Pendahuluan}

Eksistensi ekonomi Islam belum begitu dikenal pada sekitar tahun 1950-an apalagi berbentuk sebuah konsep yang termasuk dalam kriteria bangunan disiplin ilmiah. Ketika itu, sedang berlangsungnya zaman keemasan ideologi ekonomi sosialisme dan kapitalisme sehingga sistem ekonomi Islam masih belum bisa menunjukkan eksistensinya sebagai sistem yang kental dengan muatan keadilan dan kebersamaan, walaupun sebenarnya pada masa awal sejarah perkembangan Islam abad ke-7, Islam sudah memiliki sistem ekonomi yang difungsikan sebagai pengatur aktivitas ekonomi. Seiring dengan berjalannya waktu, sejarah menjadi saksi akan kekeroposan dua sistem yang pernah merajai dunia itu. ${ }^{1}$ Sosialisme yang muncul pada abad ke-19 hingga awal abad ke-20 dengan semangat kaum buruh industri dan buruh tani berdasarkan prinsip solidaritas. Kapitalisme belakangan ini mulai menunjukkan tandatanda kehancuran. Semenjak sistem kapitalisme mendominasi sistem perekonomian dunia, hampir semua negara pernah mengalami krisis yang menggoyahkan stabilitas. Krisis demi krisis ekonomi terus berulang dalam sejarah. Tercatat sejak tahun 1923, tahun 1930, tahun 1940, tahun 1970, tahun 1980, tahun 1990, dan dan tahun 1998-

\footnotetext{
1 Adiwarman Azwar Karim, :Sejarah Pemikiran ekonomi islam”, Ed. 3; Cet. 5, (Jakarta; PT RajaGrapindo Persada, 2012), h. 3-6.
} 
2001, bahkan pada tahun 2008 krisis semakin mengkhawatirkan dengan munculnya krisis finansial di Amerika Serikat, yang memberikan efek domino ke berbagai negara di penjuru dunia. Sepanjang Abad ke-20 telah terjadi lebih 20 kali krisis besar yang melanda banyak negara. Ini berarti, rata-rata setiap 5 tahun terjadi krisis keuangan hebat yang mengakibatkan penderitaan bagi jutaan umat manusia. ${ }^{2}$

Sejumlah fakta dan data di atas menjadi sebuah momentum yang berharga bagi sistem ekonomi Islam untuk membuktikan keunggulan dan keistimewaannya kepada masyarakat dunia. Imunitas ini memberikan dampak positif terhadap tingginya tingkat aseptabilitas masyarakat terhadap perkembangan ekonomi Islam, ${ }^{3}$ baik pada level Nasional maupun International.

Alqur'an dan Sunah tidak bisa dipungkiri merupakan sumber khazanah keilmuan dan buku pedoman umat Islam, namun pada saat yang bersamaan harus diakui bahwa perkembangan mutakhir belakangan ini menuntut adanya rekontekstualisasi pelajaran yang terkandung didalamnya dalam rangka menjawab persoalan umat sebagai konsekuensi zaman yang berbeda demikian juga halnya dengan kompilasi yang disepakati ulama klasik (fikih). Indonesia sebagai salah satu negara yang memiliki lembaga lembaga Perekonomian yang dikelola oleh pemerintah dan swasta, membutuhkan pengelolaan secara profesional, mandiri dan akuntabel untuk menghasilkan profit yang menjadi tujuan pembentukan lembaga lembaga tersebut. Lembaga-lembaga perekonomian yang dimaksud biasa di sebut dengan sektor publik. Sektor publik diartikan sebagai suatu entitas yang aktivitasnya berhubungan dengan usaha untuk menghasilkan barang dan pelayanan publik dalam rangka memenuhi kebutuhan dan hak publik yang terbatas. Sektor publik berkaitan dengan membenarkan keberadaan pemerintah dan memiliki pengaruh besar dalam berlangsungnya penyelenggara pemerintah dan swasta. Melihat peran dan pengaruh besar tersebut, maka sangat perlu untuk dipahami pengelolaan sektor publik secara tepat dan benar untuk mewujudkan perekonomian bangsa yang mandiri sebagaimana yang tertuang dalam tujuan pembangunan jangka panjang Indonesia yaitu mewujudkan masyarakat adil dan sejahtera khususnya dalam pemenuhan kebutuhan pokok masyarakat.

Mengingat bangsa Indonesia yang berpenduduk mayoritas Islam maka regulasi pengelolaan sektor publik diupayakan berorientasi pada ekonomi syariah. Demikian pula dalam pengelolaan harta harta publik atau harta harta negara yang dihasilkan oleh sektor sektor publik dalam meningkatkan pendapatan negara.

\section{Pembahasan}

Istilah ekonomi sektor publik itu sendiri juga bermacam-macam, hal tersebut dapat dilihat dari luasnya wilayah publik, sehingga setiap disiplin ilmu memiliki cara pandang dan definisi yang berbeda-beda. dari sudut pandang ekonomi itu sendiri, ekonomi sektor publik diartikan sebagai suatu entitas yang aktivitasnya berhubungan dengan usaha untuk menghasilkan barang dan pelayanan publik dalam

2 Ayief Fathurrahman, "Meninjau Ulang Landasan Normatif Perbankan Syariah Di Indonesia (Telaah Atas Teori Kontruksi Fikih Klasik)”, Jurnal Mawarid Vol. XI, No.1 Februari-Agustus 2010, h. 54.

${ }^{3}$ Veithzal Rivai, Bank and Financial Institution Management Conventional \& Sharia System,. (Jakarta: PT RajaGrapindo Persada, 2007), h. 24. 
rangka memenuhi kebutuhan dan hak publik yang terbatas. Sektor publik yang sering pila disebut sebagai sektor negara (state sector), merupakan bagian dari negara yang berurusan dengan pemberian, produksi alokasi barang dan jasa oleh dan untuk pemerintah atau warga negara baik nasional, regional atau yang bersifat lokal . Pengertian sektor publik lebih dimaksudkan kepada barang dan layanan publik yang ketersediaannya merupakan tanggung jawab dari pemerintah ${ }^{4}$

Definisi tersebut dapat disimpulkan bahwa Ekonomi Sektor Publik adalah studi tentang isu ekonomi yang terjadi pada sector publik (termasuk pemerintahan) dan sektor swasta dalam ekonomi campuran.serta sektor publik ekonomi telah berkaitan dengan studi tentang bagaimana pemerintah dapat menangani kegagalan pasar untuk mencapai hasil yang efisien. Ekonomi sektor publik juga menyangkut masalah ekonomi berkaitan dengan pemerintah dan dengan sektor swasta. Ini terlihat pada fungsi pemerintah dan peran mereka dalam mempromosikan sosial ekonomi kesejahteraan. ${ }^{5}$ Penjabaran Publik dalam ruang lingkup ekonomi sektor publik yakni pemberian pelayanan dengan mengutamakan pelayanan yang terjangkau untuk masyarakat, atau dalam arti lain penyediaan barang oleh pemerintah melalui dana pajak, sepenuhnya milik publik dan semua warga negara berhak menikmatinya. Karena disini mendapat dukungan langsung dari pemerintah. Barang publik ini diantaranya udara, cahaya matahari, papan marka jalan, lampu lalu lintas, pertahanan nasional, pemerintahan dan sebagainya. Akan sulit untuk menentukan siapa saja yang boleh menggunakan papan marka jalan misalnya, karena keberadaannya memang untuk konsumsi semua orang.

Penjabaran Swasta (privat) dalam ruang lingkup ekonomi sektor publik, yakni pemberian pelayanan kepada masyarakat tetapi mengutamakan dalam mendapatkan profit (keuntungan). Dalam swasta tersebut juga menyagkut tentang barang swasta (privat). Barang privat adalah barang yang diperoleh melalui mekanisme pasar, dimana titik temu antara produsen dan konsumen adalah mekanisme harga.Sebagian besar barang yang kita konsumsi adalah barang privat, yaitu barang yang hanya dapat digunakan oleh satu konsumen pada satu waktu. Misalnya, ketika seseorang sedang memakan kue miliknya, orang lain tidak dapat melakukan hal serupa.

\section{Ruang Lingkup Ekonomi Sektor Publik}

Ekonomi sektor publik memiliki beberapa ruang lingkup, diantaranya adalah relevansinya dengan pengertian ekonomi sektor publik, peran ekonomi sektor publik, dan fungsi dari ekonomi sektor publik itu sendiri. maka dari itu penulis akan membahas satu persatu sebagai berikut :

\section{a. Peranan Sektor Publik}

Posisi ekonomi sektor publik bertujuan utuk memberikan suatu prasarana, serta meningkatkan kebutuhan ekonomi masyarakat, selain sebagai sektor yang memproduksi barang dan jasa untuk pertahanan pendidikan, dan keamanan serta segala sesuatu yang terkait dengan ekonomi sektor publik. Beberapa peranan yang diberikan oleh ekonomi sektor publik adalah sebagai berikut:

1. Untuk mengkondusifkan sektor ekonomi;

\footnotetext{
${ }^{4}$ Nurul Huda dkk ; Keuangan Publik Islam, Pendekatan Teoritis dan sejarah; Edisi I (Jakarta : Kencana Prenada Media Group 2012),Hal;3

${ }^{5}$ Nurul Huda dkk; Keuangan Publik Islam, Pendekatan Teoritis dan sejarah; Edisi I (Jakarta : Kencana Prenada Media Group 2012),Hal;3
} 
2. Untuk memfasilitasi pertumbuhan dan daya saing industry dan sector swasta;

3. Untuk mendukung kebutuhan tenaga kerja,serta;

4. Untuk meningkatkan kualitas hidup warga negara;

5. Menyediakan sebuah kerangka/lapangan pekerjaan berbasis system legal yang diperlukan untuk membawa perekonomian ke fungsinya semula;

6. Memproduksibarangdanjasayangbergunauntukpertahanan, pendidikan,keam anaan, perhubungan, dan sebagainya.

7. Membeli barang dan jasa dari sektor swasta dan kemudian menyalurkannya ke perusahaan dan rumah tangga

8. Melakukan redistribusi pada pendapatan

\section{b. Fungsi Ekonomi Sektor Publik}

Sebelumnya telah dipaparkan gambaran ekonomi sektor publik dengan beberapa peranannnya. Hal itu tentutnya memberikan implikasi pada suatu negara maupun warga negara dalam suatu wilayah. Oleh karenanya, selain peranan ekonomi sektor publik, selanjutnya adalah fungsi ekonomi sektor publik, yaitu sebagai berikut:

1. Mempromosikan pembangunan ekonomi yang cepat dan memberikan dasar infra struktur fasilitas untuk pertumbuhan ekonomi, memberikan ditempatkan dan infra struktur fasilitas nilai untuk pertumbuhan ekonomi;

2. Melakukan kegiatan ekonomi strategis dan penting bagi pertumbuhan negara ini, yang jika kegiatan ekonomi strategis ditangani oleh swasta, swasta akan mendistorsi tujuan pembangunan nasional;

3. Melakukan lingkungan kegiatan ekonomi yang strategis dan penting bagi pertumbuhan suatu negara;

4. Mencapai pembangunan daerah yang seimbang dan penyebaran kegiatan ekonomi melalui pertumbuhan dan diversifikasi kegiatan ekonomi di daerah kurang berkembang dengan menyediakan infrastruktur yang memadai dan melakukan program konservasi dan pengembangan sumber daya nasional;

5. Mencapai pembangunan daerah yang seimbang atau sesuai porsi, untuk mengurangi perbedaan pendapatan antar satu daerah dengan daerah yang lainnya;

6. Mengurangi permanent differences pendapatan;

7. Menghindari konsentrasi kantong-kantong ekonomi di beberapa bagian;

8. Melakukan kontrol sosial dan pengaturan pembiayaan jangka panjang melalui lembaga keuangan publik, dan lain-lain.

Selain beberapa hal tersebut, hal mendasar lainnya adalah sebagai berikut:

\section{Pemenuhan Kebutuhan Pokok}

Strategi pemenuhan kebutuhan pokok berupa barang (pangan, sandang dan dilakukan secara bertahap. Ada beberapa langkah yang dapat ditempuh negara.

Langkah pertama:

Memerintahkan Kepada Setiap Kepala Keluarga untuk Bekerja. Barang-barang kebutuhan pokok tidak mungkin diperoleh, kecuali apabila manusia berusaha mencarinya. Islam mendorong manusia agar bekerja, mencari rezeki dan berusaha. Bahkan Islam telah menjadikan mencari rezeki tersebut adalah fardhu/wajib. Allah SWT berfirman: "Dialah (Allah) yang menjadikan bumi itu mudah bagi kamu, maka 
berjalanlah di segala penjurunya, serta makanlah sebagian rezeki-Nya." (QS. Al-Mulk $: 15)^{6}$

Nash tersebut memberikan penjelasan kepada kita, bahwa pada mulanya, pemenuhan kebutuhan pokok dan upaya meningkatkan kesejahteraan hidup manusia adalah tugas individu itu sendiri, yakni dengan "bekerja".

Langkah kedua:

Negara menyediakan berbagai fasilitas lapangan kerja agar setiap orang yang mampu bekerja dapat memperoleh pekerjaan.jika orang-orang yang wajib bekerja telah berupaya mencari pekerjaan, namun ia tidak memperoleh pekerjaan, sementara ia mampu bekerja dan telah berusaha mencari pekerjaan tersebut, maka negara wajib menyediakan lapangan pekerjaan atau memberikan berbagai fasilitas agar orang yang bersangkutan dapat bekerja untuk mencari nafkah penghidupan. Sebab, hal itu memang menjadi tanggung jawab negara. Rasullah saw bersabda : "Seorang Imam/pemimpin adalah pemelihara dan pengatur urusan (rakyat), dan ia akan diminta pertanggungjawaban terhadap urusan rakyatnya." (HR. Bukhari dan Muslim).

Dalam riwayat lain disebutkan bahwa Rasulullah saw. pernah memberikan dua dirham kepada seseorang, kemudian beliau saw. berkata kepadanya: "Makanlah dengan satu dirham, dan sisanya belikanlah kapak, lalu gunakanlah ia untuk bekerja."

Syaikh Abdul Aziz Al Badri rahimahullah menceritakan suatu ketika Amirul Mukminin, Umar bin Khathab ra. memasuki sebuah masjid di luar waktu salat lima waktu. Didapatinya ada dua orang yang sedang berdoa kepada Allah SWT. Umar ra. lalu bertanya :"Apa yang sedang kalian kerjakan, sedangkan orang-orang di sana kini sedang sibuk bekerja? Mereka menjawab :"Ya Amirul Mukminin, sesungguhnya kami adalah orang-orang yang bertawakal kepada Allah SWT." Mendengar jawaban tersebut, maka marahlah Umar ra., seraya berkata :"Kalian adalah orang-orang yang malas bekerja, padahal kalian tahu bahwa langit tidak akan menurunkan hujan emas dan perak." Kemudian Umar ra. mengusir mereka dari masjid namun memberi mereka setakar biji-bijian. Beliau katakan kepada mereka: "Tanamlah dan bertawakallah kepada Allah."

\section{Langkah Ketiga:}

Mewajibkan kepada tetangga terdekat yang mampu untuk memenuhi sementara kebutuhan pokok (pangan) tetangganya yang kelaparan. Jika seseorang tidak mampu memberi nafkah terhadap orang-orang yang menjadi tanggung jawabnya, baik terhadap sanak keluarganya atau mahramnya, dan ia pun tidak memiliki sanak kerabat atau mahram yang dapat menanggung kebutuhannya, maka kewajiban pemberian nafkah itu beralih kepada Baitul Mal (perbendaharaan negara). Namun sebelum kewajiban tersebut beralih kepada negara, dalam rangka menjamin hak hidup orang-orang yang tidak mampu tersebut, maka Islam juga telah mewajibkan kepada tetangga dekatnya yang muslim untuk memenuhi kebutuhan-kebutuhan pokok orang-orang tersebut, khususnya berkaitan dengan kebutuhan pangan untuk menyambung hidup. Bantuan tetangga itu tentunya hanya bersifat sementara, sehingga tetangganya tidak meninggal karena kelaparan. Untuk jangka panjang, maka negara yang berkewajiban untuk memenuhi kebutuhan pokoknya. Sebab, Baitul Mal (perbendaharaan negara) memang berfungsi

\footnotetext{
“"Al-Qur'an Dan Terjemahnya”,Departemen Agama Republik Indonesia
} 
menjadi penyantun bagi orang-orang yang lemah dan membutuhkan, sedangkan pemerintah adalah pemelihara dan pengatur urusan rakyatnya.

Langkah keempat:

Negara secara langsung memenuhi kebutuhan pangan, sandang dan papan seluruh warga negara yang tidak mampu dan membutuhkan. Menurut Islam, Baitul Mal berfungsi menjadi penyantun orang-orang lemah dan membutuhkan, sedangkan pemerintah adalah pemelihara dan pengatur urusan rakyatnya. Dalam hal ini negara akan diminta pertanggungjawaban terhadap rakyat yang menjadi tanggungannya. Dalam rangka memenuhi kebutuhan pokok individu masyarakat yang tidak mampu memenuhi kebutuhannya secara sempurna -baik karena mereka telah berusaha namun tidak cukup (fakir dan miskin) atau pun terhadap orang-orang yang lemah dan cacat yang tidak mampu untuk bekerja- maka negara harus menempuh berbagai cara untuk memenuhi kebutuhan hidup mereka.

Negara bisa saja memberikan nafkah dari Baitul Mal tersebut berasal dari harta zakat yang merupakan kewajiban Syar'i, dan diambil oleh negara dari orang-orang kaya, sebagaimana firman Allah SWT: "Ambillah zakat dari sebagian harta mereka, dengan zakat itu kamu membersihkan dan mensucikan mereka..." (QS. At-Taubah $: 103)^{7}$

Dalam hal ini negara berkewajiban menutupi kekurangan itu dari harta benda Baitul Mal (di luar harta zakat) jika harta benda dari zakat tidak mencukupi. Pangan dan sandang adalah kebutuhan pokok manusia yang harus terpenuhi. Tidak seorang pun yang dapat melepaskan diri dari dua kebutuhan itu. Oleh karena itu, Islam menjadikan dua hal itu sebagai nafkah pokok yang harus diberikan kepada orang-orang yang menjadi tanggung jawabnya. Demikianlah, negara harus berbuat sekuat tenaga dengan kemampuannya, sesuai dengan ketentuan-ketentuan Islam, yang bertujuan untuk mewujudkan kemaslahatan dan memungkinkan dinikmati oleh setiap individu yang tidak mampu meraih kemaslahatan itu.

\section{Pemenuhan kebutuhan pokok berupa pendidikan, kesehatan dan keamanan.}

Pendidikan, kesehatan dan keamanan, adalah kebutuhan asasi dan harus dikecap oleh manusia dalam hidupnya. Berbeda dengan kebutuhan pokok berupa barang (pangan, sandang dan papan), di mana Islam melalui negara menjamin pemenuhannya melalui mekanisme yang bertahap. Maka terhadap pemenuhan kebutuhan jasa pendidikan, kesehatan dan keamanan dipenuhi negara secara langsung kepada setiap individu rakyat. Hal ini karena pemenuhan terhadap ketiganya termasuk masalah "pelayanan umum" (ri'ayatusy syu-uun) dan kemaslahatan hidup terpenting. Islam telah menentukan bahwa yang bertanggung jawab menjamin tiga jenis kebutuhan dasar tersebut adalah negara. Negaralah yang harus mewujudkannya, agar dapat dinikmati seluruh rakyat, baik muslim maupun non-muslim, miskin atau kaya. Sedangkan seluruh biaya yang diperlukan, ditanggung oleh Baitul Maal.

Masalah pendidikan, menjadi tanggung jawab negara untuk menanganinya, dan termasuk kategori kemaslahatan umum yang harus diwujudkan oleh negara agar dapat dinikmati seluruh rakyat. Gaji guru, misalnya, adalah beban yang harus dipikul negara

\footnotetext{
7"Al-Qur'an Dan Terjemahnya”,Departemen Agama Republik Indonesia
} 
dan pemerintah dan diambil dari kas Baitul Mal. Rasulullah SAW telah menetapkan kebijaksanaan terhadap para tawanan perang Badar. Beliau katakan bahwa para tawanan itu bisa bebas sebagai status tawanan, apabila seorang tawanan telah mengajarkan 10 orang penduduk Madinah dalam baca-tulis. Tugas itu menjadi tebusan untuk kebebasan dirinya.

Dipahami bahwa barang tebusan itu tidak lain adalah hak milik Baitul Mal. Tebusan itu nilainya sama dengan harta pembebasan dari tawanan lain dalam perang Badar itu. Dengan tindakan tersebut (yakni membebankan pembebasan tawanan itu ke Baitul Mal dengan cara menyuruh para tawanan tersebut mengajarkan kepandaian bacatulis), berarti Rasulullah SAW telah menjadikan biaya pendidikan itu setara dengan barang tebusan. Artinya, beliau SAW, memberi upah kepada para pengajar itu dengan harta benda yang seharusnya menjadi milik Baitul Mal.

Pendidikan adalah kewajiban yang harus dilakukan oleh manusia. Sementara negara berkewajiban menjadikan saran-sarana dan tempat-tempat pendidikan. Rasulullah SAW bersabda: "Mencari ilmu adalah kewajiban atas setiap muslim dan muslimah" (HR Thabrani).

Mencari ilmu adalah kewajiban yang harus dipikul oleh setiap individu (fardlu 'ain). Ilmu-ilmu lain yang bersifat fardlu kifayah (fardlu atas sebagian kaum muslimin) tidak akan gugur kewajiban mencarinya sebelum sebagian kaum muslimin berhasil melaksanakannya dalam batas yang mencukupi. Misalnya ilmu ekonomi, kedokteran, industri, elektronika, mekanika dan ilmu-ilmu lain yang sangat bermanfaat dan dibutuhkan dalam kehidupan kaum muslimin.

Adapun yang berhubungan dengan jaminan kesehatan, diriwayatkan bahwa Mauquqis, Raja Mesir, pernah menugaskan (menghadiahkan) seorang dokter (ahli pengobatan)nya untuk Rasulullah SAW. Oleh Rasulullah SAW, dokter tersebut dijadikan sebagai dokter kaum muslimin dan untuk seluruh rakyat, dengan tugas mengobati setiap anggota masyarakat yang sakit. Pada masa lalu, Daulah Islamiyah telah menjalankan fungsi ini dengan sebaik-baiknya. Negara menjamin kesehatan masyarakat, mengatasi dan mengobati orang-orang sakit, serta mendirikan tempattempat pengobatan. Rasulullah SAW pernah membangun suatu tempat pengobatan untuk orang-orang sakit dan membiayainya dengan harta benda Baitul Maal.

Diceritakan bahwa Sayyidina Umar ra telah memberikan sesuatu dari Baitul Maal untuk membantu suatu kaum yang terserang penyakit lepra di jalan menuju Syam, ketika melewati daerah tersebut. Hal yang sama juga pernah dilakukan oleh para Khalifah dan wali-wali (para pemimpin wilayah). Bahkan, Khalifah Walid bin Abdul Malik telah khusus memberikan bantuan kepada orang-orang yang terserang penyakit lepra. Dalam bidang pelayanan kesehatan ini, Bani Ibnu Thulun di Mesir, memiliki masjid yang dilengkapi dengan tempat-tempat untuk mencuci tangan, lemari tempat menyimpan minuman-minuman dan obat-obatan serta, dilengkapi dengan ahli pengobatan (dokter) untuk memberikan pengobatan gratis kepada orang-orang sakit. Jadi, keberadaan dokter di tengah masyarakat, terpecahnya problema kesehatan masyarakat, dan pembangunan sarana atau balai-balai kesehatan, adalah tugas-tugas yang dibebankan Islam terhadap negara. Negaralah yang bertanggung jawab terhadap perwujudan semua itu.

Dijadikannya keamanan sebagai salah satu kebutuhan (jasa) yang pokok mudah dipahami, sebab tidak mungkin setiap orang dapat menjalankan seluruh aktivitasnya 
terutama aktivitas yang wajib seperti kewajiban ibadah, kewajiban bekerja, kewajiban bermuamalat secara Islami termasuk menjalankan aktivitas pemerintahan sesuai dengan ketentuan Islam tanpa adanya keamananan yang menjamin pelaksanaannya. Untuk melaksanakan ini semua maka negara haruslah memberikan jaminan keamanan bagi setiap warga negara.l

Adapun yang menjadi rujukan bahwa keamanan adalah salah satu kebutuhan jasa pokok adalah sabda Rasulullah saw : "Barangsiapa yang ketika memasuki pagi hari mendapati keadaan aman kelompoknya, sehat badannya, memiliki bahan makanan untuk hari itu, maka seolah-olah dunia telah menjadi miliknya." (Al-Hadits).

Mekanisme untuk menjamin keamanan setiap anggota masyarakat, adalah dengan jalan menerapkan aturan yang tegas kepada siapa saja yang akan dan mengganggu keamanan jiwa, darah dan harta orang lain. Sebagai gambaran kepada siapa saja yang mengganggu keamanan jiwa orang lain, yakni dengan jalan membunuh orang lain, maka orang tersebut menurut Islam harus dikenakan sanksi berupa qishash, yakni balasan yang setimpal kepada orang yang melakukan kejahatan tersebut. Termasuk di dalamnya keamanan harta milik pekerja dari upah yang seharusnya mereka miliki. Serta keamanan harta milik pengusaha dari perusahaan dan aset yang mereka miliki. Menjadi jelas bahwa Islam memberikan jaminan terhadap pemenuhan kebutuhan pokok setiap warga masyarakat, berupa pangan, sandang, papan. Demikian juga Islam telah menjamin terselenggaranya penanganan masalah pendidikan, kesehatan dan keamanan. Dijadikannya semua itu sebagai kewajiban negara dan bagian dari tugasnya sebagai pemelihara dan pengatur urusan rakyat. Negaralah yang melaksanakan dan menerapkannya berdasarkan syari'at Islam.

Penerapan politik ekonomi Islam tersebut, dapat menjadi solusi beberapa permasalahan pokok ketenagakerjaan, sehingga masalah yang berkaitan dengan pemenuhan kebutuhan pokok dapat diatasi. Pengangguran diharapkan akan berkurang karena ketersedian lapangan kerja dapat di atasi; masalah buruh wanita dan pekerja di bawah umur tidak akan muncul karena mereka tidak perlu harus terjun ke pasar tenaga kerja untuk mencari nafkah memenuhi kebutuhan hidupnya. Demikian permasalahan tunjangan sosial berupa pendidikan dan kesehatan bukanlah masalah yang harus dikhawatirkan pekerja. Termasuk jaminan untuk memperoleh upah yang menjadi hak pekerja dapat diberikan.

\section{A. Harta Publik /Harta Negara}

Menurut kamus Bahasa Indonesia asset (harta) adalah kekayaan atau modalatau secara luas bisa juga dimaknai bahwa aset adalah sebuah sumber ekonomi yang diharapkan dapat memberikan manfaat usaha di masa mendatang ${ }^{8}$

مال- يميل- ميلا Harta dalam bahasa Arab disebut, al-mal yang berasal dari kata yang berarti condong, cenderung, dan miring (manusia cenderung ingin memiliki dan menguasai harta). ${ }^{9}$ Harta yang telah ditetapkan hak miliknya oleh as-syari' (Allah), dan menjadikan harta tersebut milik bersama.Kepemilikan(harta) publik adalah seluruh kekayaan yang telah ditetapkan kepemilikannya oleh Allah bagi kaum muslim sehingga kekayaan tersebut menjadi milik bersama kaum muslim. Individu-individu dibolehkan

\footnotetext{
${ }^{8}$ Meity Taqdir Qodratullah, Kamus Bahasa Indonesia untuk Pelajar, (Jakarta: BPPB Kemendikbud RI, 2011), hlm 552.

${ }^{9}$ Dr. H. Hendi Suhendi, M.Si, Fiqih Muamalah. Jakarta:Rajawali Pers, 2010, hlm. 9
} 
mengambil manfaat dari kekayaan tersebut, namun terlarang memilikinya secara pribadi.

\section{Jenis dan macam Harta Publik}

Setidak-tidaknya, benda yang dapat dikelompokkan ke dalam kepemilikan umum ini, ada tiga jenis, yaitu: ${ }^{10}$

1. Harta milik umum jenis pertama.

Harta milik umum jenis pertama adalah barang tambang (sumber alam) yang jumlahnya tak terbatas, yaitu barang tambang yang diprediksi oleh para ahli pertambangan mempunyai jumlah yang sangat berlimpah. Hasil dari pendapatannya merupakan hasil milik bersma dan dapat dikelola oleh negara, atau negara menggaji tim ahli dalam pengelolaannya. Adapun barang yang jumlahnya sedikit dan sangat terbatas dapat digolongkan kedalam milik pribadi. Hal ini seperti Rasulullah SAW, membolehkan bilal bin Harist al-Mazany memiliki barang tambang yang sudah ada (sejak dahulu) dibagian wilayah hijaz, pada saat itu bilal telah meminta kepada Rosulullah agar memberikan daerah tambang tersebut kepadanya, dan beliaupun memberikannya kepada bilal dan boleh dimilikinya.

Oleh karena itu pertambangan emas, perak dan barang tambang lainnya yang jumlah (depositnya) sangat sedikit tidak ekonomis dan bukan untuk diperdagangkan maka digolongkan milik pribadi. Seseorang boleh memilikinya seperti halnya juga Negara boleh memberikan barang tambang seperti itu kepada mereka. Hanya saja mereka membayar khumus (seperlima) dari yang diproduksinya kepada baitul mal, baik yang dieksploitasinya itu sedikit ataupun banyak. Adapun barang tambang yang jumlahnya banyak dan (depositnya) tidak terbatas, menurut Abdullah, tergolong pemilikan umum bagi seluruh rakyat, sehingga tidak boleh dimiliki oleh seorang atau beberapa orang. Tidak boleh diberikan kepada seorang ataupun orang tertentu. Menurut al-Maliki, tidak ada perbedaan antara barang tambang terbuka (terdapat dipermukaan bumi), yang ekploitasinya tidak memerlukan usaha yang berat, seperti garam, dan (batu) celak mata, dengan barang tambang yang terdapat diperut bumi, yang eksploitasinya memerlukan usaha yang berat, seperti emas, perak, besi, tembaga, maupun yang bentuk cair seperti minyak bumi, atau berbentuk gas seperti gas alam.

2. Harta milik umum jenis kedua.

Harta milik umum jenis kedua adalah sarana umum diperlukan bagi seluruh rakyat yang diperlukan dalam pemenuhan hidup sehari-hari, yang tidak akan menyebabkan perpecahan, seperti air. Rasulullah telah menjelaskan mengenai sifat-sifat saran umum, dalam hal ini dari hadist Ibnu Abbas, bahwa Rasulullah SAW bersabda:

"kaum Muslim itu berserikat dalam tiga hal, yaitu air, padang rumput, dan api"

Air, padang rumput dan api merupakan sebagian harta yang pertama kali diperbolehkan Rasulullah umtuk seluruh manusia. Harta ini tidak terbatas yangdisebutkan pada hadist diatas, tetapi meliputi setiap benda yang didalamnya terdapat sifat-sifat sarana umum.

Mencermati secara tepat, maka apa yang disebut sarana umum adalah bahwa seluruh manusia membutuhkannya dalam kehidupan sehari-hari. Dan jika sarana tersebut hilang maka manusia kesusahan dalam mencarinya. Setiap alat yang dipergunakan di dalamnya, karena dan status kepemilikannya sama, yaitu sebagai milik

\footnotetext{
${ }^{10}$ http://www.blogger.com/blogger?
} 
umum. Demikian juga alat-alat pembangkit listrik yang dibangun diatas air (sumber) keperluan seperti saluran dan sungai, tiang-tiang penyangganya, dan alat-alat lain yang diperlukan, sebab alat-alat ini menghasilkan listrik dari hasil umum, sehingga status alat-alat ini juga sama milik umum. Menurut Labib, jika alat pembangkit listrik merupakan bagian dari kepemilikan umum maka tidak boleh dimiliki oleh perseorangan, hal ini disebabkan penguasaan dalam kepemilikan umum dilarang oleh negara. Dan begitu juga sebaliknya, dalam artian jika semua sarana dimilki individu atau perusahaan maka boleh memilikinya secara pribadi. Demikian pula jalan umum, manusia berhak lalu lalang di atasnya. Oleh karenanya, penggunaan jalan yang dapat merugikan orang lain yang membutuhkan, tidak boleh diizinkan oleh penguasa. Hal tersebut juga berlaku untuk Masjid. Termasuk dalam kategori ini adalah kereta api, instalasi air dan listrik, tiang-tiang penyangga listrik, saluran air dan pipa-pipanya, semuanya adalah milik umum sesuai dengan status jalan umum itu sendiri sebagai milik umum, sehingga ia tidak boleh dimiliki secara pribadi.

3. Harta milik umum jenis ketiga.

Harta milik yang ketiga adalah harta yang keadaan asal pembentukannya menghalangi seseorang untuk memilikinya secara pribadi. Menurut al-Maliki, hak milik umum jenis ini jika berupa sarana umum seperti halnya kepemilikan jenis pertama, maka dalil yang mencakup saran umum.Hanya saja jenis kedua ini menurut asal pembentukannya menghalangi seseorang untuk memilikinya, sehingga misalnya boleh memiliki secara hajat keperluan orang banyak (umum).

Demikian juga halnya dengan jalan umum, Rasulullah SAW menyatakan bahwa manusia berhak atas jalan umum tersebut, artinya mereka berhak untuk melewati jalan tersebut, dan menjauhkan duri/batu dari jalan umum adalah sedekah. Jika kita melihat faktanya, kondisi asal pembentukannya menghalangi seseorang untuk menghalangi orang lain menguasai dan memilikinya. Seperti tentang jalan umum yang dibuat untuk seluruh manusia, dan mereka bebas untuk melewatinya, dan seorang pun tidak boleh memilikinya. Larangan ini bersifat tetap. Dengan kata lain tidak ada penguasa/pemagaran atas harta milik umum kecuali oleh negara. Karena api, tiang-tiang penyangga listrik, saluran-saluran air, pipa-pipa penyalur air yang keadaannya tetap menjadi milik jalan umum, adalah milik jalan umum. Tindakan mengambil alih sebagian jalan umum secara permanen dan mengkhususkan individu menguasainya secara terus-menerus sama saja dengan pengusaan, kecuali oleh negara. Oleh karena itu, semua yang disebutkan tadi adalah milik umum.

Barang tambang semacam ini menjadi milik umum sehingga tidak boleh dimiliki oleh perorangan atau beberapa orang. Demikian juga tidak boleh nya, memberikan keistimewaan kepada seseorang atau lembaga tertentu untuk mengeksploitasinya tetapi penguasa wajib membiarkannya sebagai milik umum bagi seluruh rakyat. Negaralah yang wajib menggalinya, memisahkannya dari benda-benda lain, menjualnya dan menyimpan hasilnya di Baitul Mal. Sedangkan barang tambang yang depositnya tergolong kecil atau sangat terbatas, dapat dimiliki oleh perseorangan atau perserikatan. Hal ini didasarkan kepada hadis nabi yang mengizinkan kepada Bilal ibn Harith alMuzani memiliki barang tambang yang sudah ada dibagian Najd dan Tihamah. Hanya saja mereka wajib membayar khumus (seperlima) dari yang diproduksinya kepada bait 
al-Mal. ${ }^{11}$ Barang-barang tambang seperti minyak bumi besarta turunannya seperti bensin, gas, dan lain-lain, termasuk juga listrik, hutan, air, padang rumput, api, jalan umum, sungai, dan laut semuanya telah ditetapkan syara' sebagai kepemilikan umum. Negara mengatur produksi dan distribusi aset-aset tersebut untuk rakyat. Pengelolaan kepemilikan umum oleh negara dapat dilakukan dengan dua cara, yakni :

Pertama, Pemanfaatan Secara Langsung oleh Masyarakat Umum.

Air, padang rumput, api, jalan umum, laut, samudra, sungai besar, adalah bendabenda yang bisa dimanfaatkan secara langsung oleh setiap individu. Siapa saja dapat mengambil air dari sumur, mengalirkan air sungai untuk pengairan pertanian, juga menggembalakan hewan ternaknya di padang rumput milik umum. Bagi setiap individu juga diperbolehkan menggunakan berbagai peralatan yang dimilikinya untuk memanfaatkan sungai yang besar, untuk menyirami tanaman dan pepohonan. Karena sungai yang besar cukup luas untuk dimanfaatkan seluruh masyarakat dengan menggunakan peralatan khusus selama tidak membuat kemudharatan bagi individu lainnya. Sebagaimana setiap individu diperbolehkan memanfaatkan jalan-jalan umum secara individu, dengan tunggangan, kendaraan. Juga diperbolehkan mengarungi lautan dan sungai serta danau-danau umum dengan perahu, kapal, dan sebagainya, sepanjang hal tersebut tidak membuat pihak lain yaitu seluruh kaum muslim dirugikan, tidak mempersempit keluasan jalan umum, laut, sungai, dan danau.

Kedua, Pemanfaatan di bawah pengelolaan negara.

Kekayaan milik umum yang tidak dapat dengan mudah dimanfaatkan secara langsung oleh setiap individu masyarakat yang membutuhkan keahlian, teknologi tinggi, serta biaya yang besar seperti minyak bumi, gas alam, dan barang tambang lainnya, maka negaralah yang berhak untuk mengelola dan mengeksplorasi bahan tersebut. Dan hasilnya dimasukkan ke dalam kas negara. Pemerintah adalah pihak yang berwenang dalam pendistribusian hasil tambang dan pendapatannya sesuai denga kemashlahatan umat. ${ }^{12}$

Negara membutuhkan hak milik untuk memperoleh pendapatan, sumber penghasilan dan kekuasaan untuk melaksanakan kewajiban-kewajibannya. Misalnya untuk menyelenggarakan pendidikan, memelihara keadilan, regenerasi moral dan tatanan masyarakat yang terjamin kesejahteraannya. Selain itu, negara juga meningkatkan sumber penghasilan dengan mengenakan pajak kepada warga negaranya, ketika dibutuhkan atau kebutuhannya meningkat. Demikian pula, berlaku bagi kekayaan yang tak diketahui pemiliknya, wakaf, hibah dan pungutan denda termasuk sumber kekayaan negara. Kekayaan negara secara aktual merupakan kekayaan umum. Kepala negara hanya bertindak sebagai pemegang amanah. Dan merupakan kewajiban negara untuk mengeluarkannya guna kepentingan umum. Oleh karena itu, sangat dilarang penggunaan kekayaan negara yang berlebih-lebihan. Adalah merupakan kewajiban negara melindungi hak fakir miskin, bekerja keras bagi kemajuan ekonomi

\footnotetext{
${ }^{11}$ Abdul Qadim Zallum, Sistem Keuangan di Negara Khilafah, hlm. 128-129.

${ }^{12}$ al-Maliki, Abd al-Rahman.,M. solahuddin,asas-asas ekonomi islam, (jakarta: pt raja grafindo
} persada,2007) 
masyarakat, mengembangkan sistem keamanan sosial dan mengurangi jurang pemisah dalam hal distribusi pendapatan.

\section{B. Kompilasi Ekonomi Syariah}

Pembahasan sebelumnya telah dijelaskan posisi sektor-sektor publik perekonomian dalam pemenuhan kebutuhan pokok masyarakat serta pengelolaaan harta publik atau harta negara sebagai bagian dari sektor-sektor publik perekonomian dalam meningkatkan pendapatan negara, selanjutnya dapat diuraikan kedudukan sector-sektor tersebut dalam Kompilasi Ekonomi Islam. Sektor-sektor publik ekonomi, pada dasarnya meliputi segala benda dan jasa yang dikelola oleh negara dan dipergunakan sebesar-besar untuk kemaslahatan masyarakat atau umat. Undang-undang Dasar 1945 pada pasal 33 ayat 1 sampai 5 sangat jelas menyebutkan bahwa sumber daya alam dikuasai oleh negara dan dipergunakan sebesa-besarnya bagi kemamuran rakyat. Dengan dasar tersebut, maka penyelenggara negara memandang perlu adanya regulasi khusus yang mengatur tentang pengelolaan perekonomian negara dalam sudut Ekonomi Islam, mengingat masyarakat Indonesia dengan penduduk mayoritas muslim, juga banyak menguasai sektor-sektor public tersebut. Kompilasi Ekonomi Syariah menyebutkan bahwa. dalam pembahaasan subyek dan amwal pada Bab I Ketentuan Umum Pasal 1, yang dimaksud dengan ekonomi syariah adalah usaha atau kegiatan yang dilakukan oleh orang perorang, kelompok orang, badan usaha yang berbadan atau tidak berbadan dalam rangka memenuhi kebutuhan yang bersifat komersial dan tidak komersial menurut prinsip syariah.

Sedangakan benda yang dapat dimiliki, dikuasai, diusahakan, dan dialihkan, baik benda berwujud maupun tidak berwujud, baik benda yang terdaftar maupun yang tidak terdaftar, baik benda yang bergerak maupun yang tidak bergerak, dan hak yang mempunyai nilai ekonomis disebut dengan amwal.

Pada pasal berikutnya (Pasal 18) meneyebutkan tentang cara perolehan benda yang dimaksud, antara lain: a. pertukaran; b. pewarisan; c. hibah; d. wasiat'; e. pertambahan alamiah; f. jual-beli; g. luqathah; h. wakaf; dan cara lain yang dibenarkan menurut syariah.

Selanjutnya pada pasal 19 mengatur tentang siifat pemilikan amwal yaitu:
a. Pemilikan yang penuh, mengharuskan adanya
kepemilikan manfaat dan tidak dibatasi waktu;

b. Pemilikan yang tidak penuh, mengharuskan adanya kepemilikan manfaat dan dibatasi wakt;

c. Pemilikan yang penuh tidak bisa dihapuskan, tetapi bisa dialihkan;

d. Pemilikan syarikat yang tidak penuh sama dengan kepemilikan terpisah tasharrufnya;

e. Pemilikan syarikat yang penuh ditasharrufkan dengan hak dan kewajiban secara proporsional.

Penjelasan Kompilasi Hukum Ekonomi Syariah atas pengelolaan sektor-sektor publik Ekonomi, sepatutnya dapat menjadi solusi dalam pengelolaan sektor-sektor publik Ekonomi, khususnya dalam pengelolaan ekonomi yang dikelola oleh muslim secara individu atau badan, maupun dalam pengelolaan kenegaraan. 


\section{Simpulan}

Ekonomi sektor publik diartikan sebagai suatu entitas yang aktivitasnya berhubungan dengan usaha untuk menghasilkan barang dan pelayanan publik dalam rangka memenuhi kebutuhan dan hak publik yang terbatas. Sektor publik yang sering pila disebut sebagai sektor negara (state sector), merupakan bagian dari negara yang berurusan dengan pemberian, produksi alokasi barang dan jasa oleh dan untuk pemerintah atau warga negara baik nasional, regional atau yang bersifat lokal. Pengertian sektor publik lebih dimaksudkan kepada barang dan layanan publik yang ketersediaannya merupakan tanggung jawab dari pemerintah.

Ekonomi sektor publik memiliki beberapa ruang lingkup, diantaranya adalah relevansinya dengan pengertian ekonomi sektor publik, peran ekonomi sektor publik, dan fungsi ekonomi sektor publik itu sendiri.

Strategi untuk pemenuhan pokok masyarakat oleh negara dapat dilakukan dengan beberapa langkah secara bertahap, antara lain :

1. Memerintahkan Kepada Setiap Kepala Keluarga untuk Bekerja.

2. Negara menyediakan berbagai fasilitas lapangan kerja agar setiap orang yang mampu bekerja dapat memperoleh pekerjaan.

3. Mewajibkan kepada tetangga terdekat yang mampu untuk memenuhi sementara kebutuhan pokok (pangan) tetangganya yang kelaparan

4. Negara secara langsung memenuhi kebutuhan pangan, sandang dan papan seluruh warga negara yang tidak mampu dan membutuhkan

Dalam pemenuhanan pokok masyarakat, negara (pemerintah) secara langsung dapat mengelola dan memanfaatkan harta harta publik/harta negara. Harta-harta publik dapat dikelompokkan dalam kepemilikan umum :

a. Harta Milik Umum jenis pertama

Harta milik umum jenis pertama adalah barang tambang (sumber alam) yang jumlahnya tak terbatas, yaitu barang tambang yang diprediksi oleh para ahli pertambangan mempunyai jumlah yang sangat berlimpah. Hasil dari pendapatannya merupakan hasil milik bersma dan dapat dikelola oleh negara, atau negara menggaji tim ahli dalam pengelolaannya

b. Harta milik umum jenis kedua

Harta milik umum jenis kedua adalah sarana umum diperlukan bagi seluruh rakyat yang diperlukan dalam pemenuhan hidup sehari-hari, yang tidak akan menyebabkan perpecahan, seperti air.

c. Harta milik umum jenis Ketiga

Harta milik yang ketiga adalah harta yang keadaannya asal pembentukannya menghalangi seseorang untuk memilikinya secara pribadi.

Pengelolaan kepemilikan umum oleh negara dapat dilakukan dengan dua cara, yakni :

1. Pemanfaatn secara langsung oleh masyarkat umum;

2. Pemanfaatan dibawah pengelolaan negara. 


\section{Daftar Pustaka}

Adiwarman Azwar Karim, :Sejarah Pemikiran ekonomi islam”, Ed. 3; Cet. 5, (Jakarta; PT RajaGrapindo Persada), 2012.

Ayief Fathurrahman, "Meninjau Ulang Landasan Normatif Perbankan Syariah Di Indonesia (Telaah Atas Teori Kontruksi Fikih Klasik)”, Jurnal Mawarid Vol. XI, No.1 Februari-Agustus), 2010.

Veithzal Rivai, Bank and Financial Institution Management Conventional \& Sharia System,. (Jakarta: PT RajaGrapindo Persada), 2007.

Al-Qur'an Dan Terjemahnya”,Departemen Agama Republik Indonesia

Abdul Qadim Zallum, Sistem Keuangan di Negara Khilafah.

al-Maliki, Abd al-Rahman.,M. solahuddin,asas-asas ekonomi islam, (jakarta: pt raja grafindo persada), 2007.

Hendi Suhendi, Fiqih Muamalah. Jakarta:Rajawali Pers, 2010.

Meity Taqdir Qodratullah, Kamus Bahasa Indonesia untuk Pelajar, (Jakarta: BPPB Kemendikbud RI), 2011.

Nurul Huda dkk ;Keuangan Publik Islam, Pendekatan Teoritis dan sejarah; Edisi I (Jakarta : Kencana Prenada Media Group), 2012. 